\title{
A re-interpretation of the "Bateman Brook Metamorphic Suite", Cape Breton Highlands, Nova Scotia, as sheared, fault-bounded blocks of other units
}

\author{
David W.A. McMullin, Sandra M. Barr and Robert P. Raeside \\ Department of Geology, Acadia University, Wolfville, Nova Scotia BOP 1XO, Canada
}

Date Received September 22, 1992

Date Accepted February 16, 1993

\begin{abstract}
The Bateman Brook Metamorphic Suite, as previously defined, is the westernmost unit of the Bras d'Or terrane in the central Cape Breton Highlands. It outcrops along the Eastern Highlands Shear Zone, the contact between the Bras d'Or terrane and the Aspy terrane to the northwest. The Bateman Brook unit has been reported to contain a wide range of lithologies, and contacts with adjacent units are mainly faulted.

Re-examination of rocks from the Bateman Brook Metamorphic Suite shows it to consist of semipelitic to psammitic schist, banded mafic gneiss, and foliated, dioritic, mafic gneiss. Rocks exhibit two major shear fabrics, an early intensely foliated and lineated fabric indicative of shear at high metamorphic grade, and a later mylonitic fabric indicative of shear at lower grade.

As a result of this study, it is recommended that the name Bateman Brook Metamorphic Suite be abandoned. The southern part of the suite is re-assigned to the McMillan Flowage Formation of the Bras d'Or terrane. The central part is interpreted to include rocks of both the Kathy Road Dioritic Suite and the McMillan Flowage Formation. Most of the northern part is re-assigned to the Jumping Brook Metamorphic Suite of the Aspy terrane.
\end{abstract}

La suite métamorphique de Bateman Brook, telle que définie antérieurement, est l'unité la plus occidentale du terrain de Bras d'Or dans le centre des hautes-terres du Cap-Breton. Elle affleure le long de la zone de cisaillement de Eastern Highlands, le contact entre le terrain de Bras d'Or et le terrain d'Aspy au nord-ouest. L'unité de Bateman Brook a été décrite comme comprenant une grande variété de lithologies et les contacts avec les unités adjacentes sont principalement faillés.

Un réexamen de roches provenant de la suite métamorphique de Bateman Brook montre qu'elle consiste en schiste semi-pélitique à psammitique, en gneiss mafique rubané et en gneiss mafique dioritique et folié. Les roches montrent deux fabriques de cisaillement majeures, une fabrique de foliation et de linéation précoce fortement développée indiquant un cisaillement à haut grade métamorphique et une fabrique mylonitique plus tardive indicative d'un cisaillement à plus faible grade.

Comme résultat de cette étude, il est recommandé que le terme de suite métamorphique de Bateman Brook soit abandonné. La partie sud de la suite est réassignée à la Formation de McMillan Flowage du terrain de Bras d'Or. La partie centrale est interprétée comme incluant des roches appartenant à la suite dioritique de Kathy Road et à la Formation de McMillan Flowage. La plupart de la partie du nord est réassignée à la suite métamorphique de Jumping Brook du terrain d'Avalon.

[Traduit par la rédaction]

\section{INTRODUCTION AND OVERVIEW}

The Bateman Brook Metamorphic Suite, as defined by Raeside and Barr (1990, 1992), crops out for a total strike length of $30 \mathrm{~km}$ at the westernmost margin of the Bras d'Or terrane in northern Cape Breton Island. The Eastern Highlands Shear Zone, the postulated boundary between the Bras d'Or and the Aspy terranes of Barr and Raeside (1989), forms much of the western boundary of the suite. As described by Raeside and Barr $(1990,1992)$, the Bateman Brook Metamorphic Suite is lithologically heterogeneous, with quartzofeldspathic rocks dominant in the southern part and mafic rocks dominant in the northern part. The quartzofeldspathic rocks consist mainly of semipelitic gneiss and pelitic migmatite, with some psammitic schist and augen gneiss and rare pink quartz-muscovite schist, and the mafic rocks are variably migmatized and banded amphibolites. The Bateman Brook Metamorphic Suite was interpreted to have been intruded by the ca. 560 Ma Kathy Road Dioritic Suite and thus to have a minimum age of Late Hadrynian. Outcrop of the rocks is generally poor, particularly in the north where the unit also appears to be most complex.

The Bateman Brook Metamorphic Suite is important in interpretations of the geology of the Cape Breton Highlands because of its location at a controversial terrane boundary (e.g., Keppie, 1990; Jamieson et al., 1991) and because of the discovery of gold occurrences in the northern part of the unit (Smith et al., 1990). The purpose of this paper is to report the results of a petrological study of the Bateman Brook Metamorphic Suite that has yielded a better understanding of the field distribution of the various rock types in the unit as well as an increased awareness of the textural and structural variations. This study indicates that the suite should not be considered a separate unit because it probably consists of juxtaposed sheared rocks that can be assigned to other map units in the area.

The following discussion begins with a description of the deformational features in the study area. The rocks of 
the Bateman Brook Metamorphic Suite are then described in three geographic areas; southern, central, and northern, centred on the areas of greatest outcrop as indicated by the concentrations of sample locations (labelled A, B, and C on Fig. 1). Because all of the components of the suite are here interpreted to be parts of other units, it is recommended that the term "Bateman Brook Metamorphic Suite" be abandoned.

\section{Shear Fabrics}

The "Bateman Brook Metamorphic Suite" occurs mainly within the Eastern Highlands Shear Zone. Originally used solely as a descriptive term for a wide zone of mylonite with unknown protolith, use of the term "Eastern Highlands Shear Zone" has extended to include sheared rocks with various but known protoliths (Lin, 1992) and has also gained some genetic or interpretative connotations as the boundary between the Bras d'Or and Aspy terranes (Barr and Raeside, 1989; Raeside and Barr, 1992). According to the latter authors, the juxtaposition of the Bras d'Or and Aspy terranes is the primary event responsible for the shear zone. However, Lynch and Tremblay (1992) and Lin (1992) proposed that the Aspy and Bras d'Or terranes of Barr and Raeside (1989) have a stratigraphic relationship (Aspy units deposited on Bras d'Or) and that the Eastern Highland Shear Zone is therefore not a terrane boundary.

North of the study area (Fig. 1), the Eastern Highlands Shear Zone (EHSZ) is up to $800 \mathrm{~m}$ wide and consists of distinctive flinty mylonites that resemble banded rhyolites (Raeside and Barr, 1992). The shear zone had been interpreted (Raeside and Barr, 1992) to continue south through the study area as narrow zones of mylonite that merge with faults in the West Branch North River Granite and along the margins of the North Branch Baddeck River Leucotonalite and Kathy Road Dioritic Suite (Fig. 1). However, Mengel et al. (1991) considered mylonite zones west of the North Branch Baddeck River Leucotonalite to be the extension of the shear zone. Mengel et al. (1991) also proposed that some faults northwest of the zone, as described by Raeside and Barr (1992), are splays from it. Farther south the EHSZ disappears beneath Carboniferous cover rocks (Raeside and Barr, 1990, 1992).

Shearing in the study area appears to have operated over an extensive time period and over variable pressure-temperature conditions (Lin, 1992). As a result not all the rocks are mylonites sensu stricto (Mawer, 1986; Hanmer and Passchier, 1991) but have a variety of fabrics produced by noncoaxial deformation (shear). The present study is based on unoriented specimens and hence interpretations of the kinematics in the study area are not possible. In his work on the EHSZ north of the study area, Lin (1992) showed that the earliest movement $\left(D_{1}\right)$ was dominantly east-over-west reverse movement on a steeply southeast-dipping shear zone and that the later movement $\left(\mathrm{D}_{2}\right)$ was dextral and transpressional with a component of west-side-up vertical movement.

In the present study area, shear fabrics are of two general types: (a) a gneissic or schistose fabric with a variably pronounced foliation and intense lineation (Fig. 2), and (b) a mylonitic fabric sensu stricto with features such as S- and Csurfaces (Hanmer and Passchier, 1991), porphyroclasts, mica "fish", ribbon grains, and sub-grain development (Fig. 3). Rocks with the mylonitic fabric (sensu stricto) also show variable sericitization and saussuritization of feldspars and chloritization of mafic minerals.

In the absence of more detailed data it is impossible to interpret the origin of these two distinctly different fabrics. They appear to be similar to the $D_{1}$ fabric (gneissic fabric) and $\mathrm{D}_{2}$ fabric (mylonitic fabric) of Lin (1992). The distribution and the difference in nature of the two fabrics, combined with the presence of alteration associated with the mylonitic fabric, imply that the mylonitic fabric postdated the gneissic fabric, which is also consistent with the observations of Lin (1992). In the study area it is not certain whether these two fabrics resulted from a single phase of deformation operating over a long period and under varying conditions, or are the result of two discrete episodes of shear. Raeside and Barr (1992) concluded, on stratigraphic and geochronologic evidence, that movement on the EHSZ north of the study area occurred over an extended period. Lin (1992) proposed that the two distinct episodes of shear $\left(D_{1}\right.$ and $\left.D_{2}\right)$ have Late Silurian to Early Devonian and Late Devonian to Early Carboniferous ages, respectively. In the study area, there appears to have been a period of dyke intrusion between the generation of the two fabrics, thus supporting a two-episode hypothesis (see below).

\section{Area A}

The southern part of the "Bateman Brook Metamorphic Suite" (area A on Fig. 1), is bounded on the east by the Kathy Road Dioritic Suite, on the west by the North Branch Baddeck River Leucotonalite, and on the north by a portion of the West Branch North River Granite. In all cases, the contacts appear to be faulted except for a possible intrusive contact with the Devonian West Branch North River Granite (O'Beirne-Ryan and Jamieson, 1986). Although outcrop is limited, the rocks in area A appear to be predominantly metasedimentary, as noted originally by Raeside and Barr $(1990,1992)$. All samples from this area are strongly foliated and appear to be mylonitic sensu stricto. Rock types include semipelitic and psammitic schist, quartz-muscovite schist, and minor amphibolite. With the exception of the quartzmuscovite schist, these rocks are similar in lithology and metamorphic grade to rocks of the McMillan Flowage Formation, which occurs east of the Kathy Road Dioritic Suite (Fig. 1). The quartz-muscovite schist does not have an obvious correlative in the McMillan Flowage Formation and is somewhat similar to felsic rocks of the Sarach Brook Metamorphic Suite in the Aspy terrane to the west. It may be sheared felsic dyke material because felsic dykes are common in the central area (area B, Fig. 1) of the "Bateman Brook Metamorphic Suite" and the adjacent Kathy Road Dioritic Suite (see below). Overall, the southern area of the "Bateman Brook Metamorphic Suite" is interpreted to be part of the 


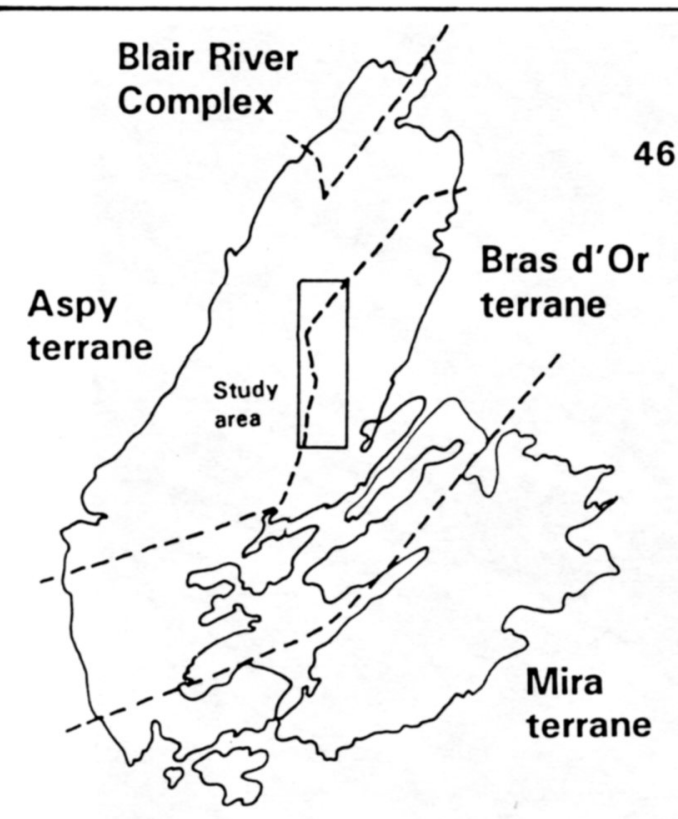

CAPE BRETON ISLAND

\section{Aspy terrane}

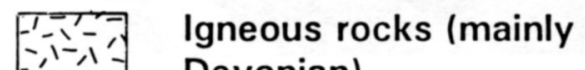
Devonian)
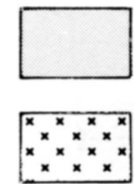

Metamorphic rocks (mainly Silurian deposition)

${ }^{x} x^{x} x^{x} \times$ N. Branch Baddeck River Leucotonalite (Hadrynian)

\section{Bras d'Or terrane}

${ }_{+}^{+}+{ }_{+}$Igneous rocks (mainly dioritic and Hadrynian)

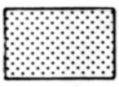

McMillan Flowage

Formation (Hadrynian)

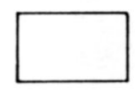

Mainly granitoid rocks of unknown age and affinity

Outcrop localities (in and near "Bateman Brook Metamorphic Suite")

$\sim$ Geologic contacts

$\sim \sim$ Faults

$\sim$ Roads

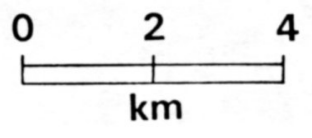

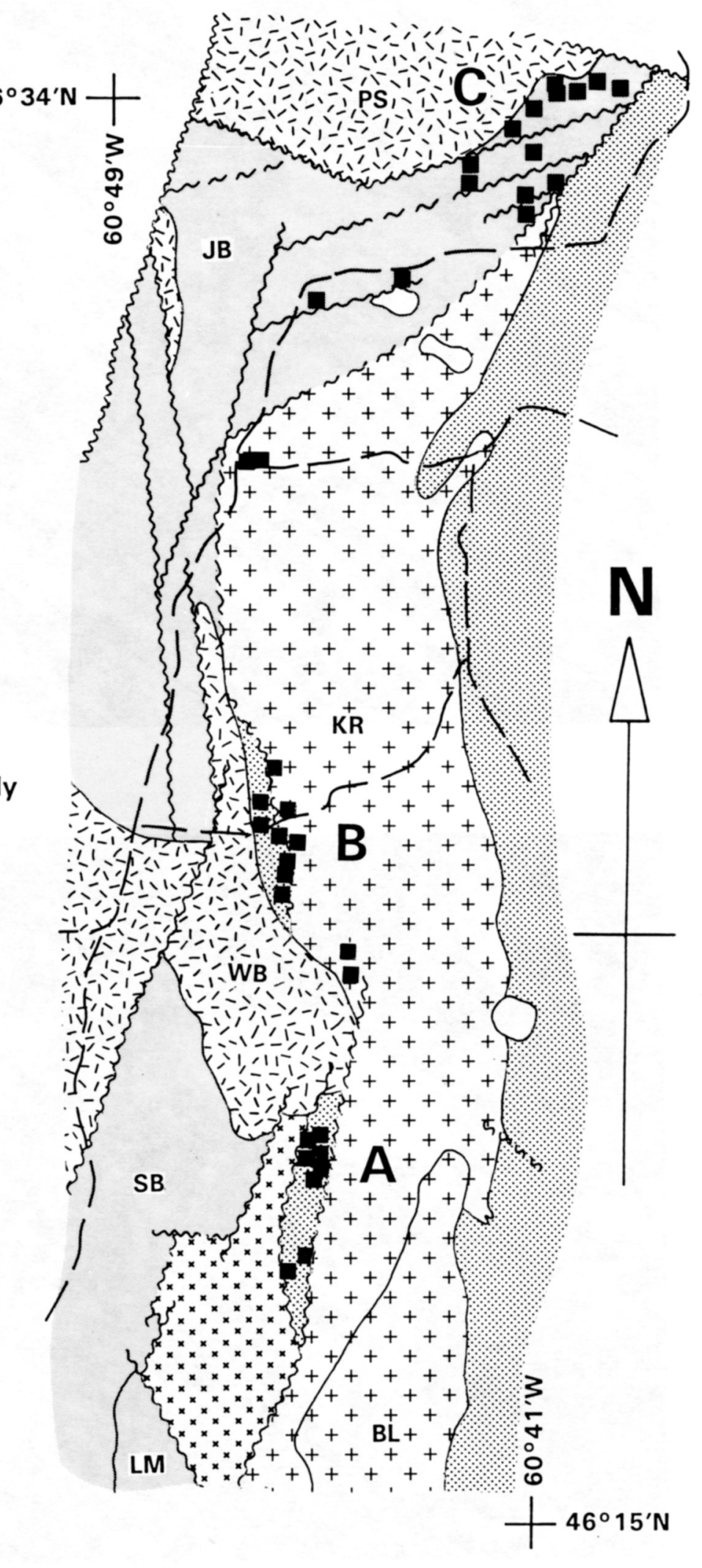

Fig. 1. Geology of part of the central Cape Breton Highlands, the northwestern part of the Bras d'Or terrane, showing the reinterpretation of the rocks originally ascribed to the "Bateman Brook Metamorphic Suite". Inset map shows location of study area. Units not specifically mentioned in the legend are labelled as follows: KR - Kathy Road Dioritic Suite, BL - Bell Lakes Suite, SB - Sarach Brook Metamorphic Suite, LM - Leonard MacLeod Brook Complex, JB - Jumping Brook Metamorphic Suite, WB - West Branch North River Granite, PS - Park Spur Granite. The letters A, B, and C refer to the general areas mentioned in the text. 

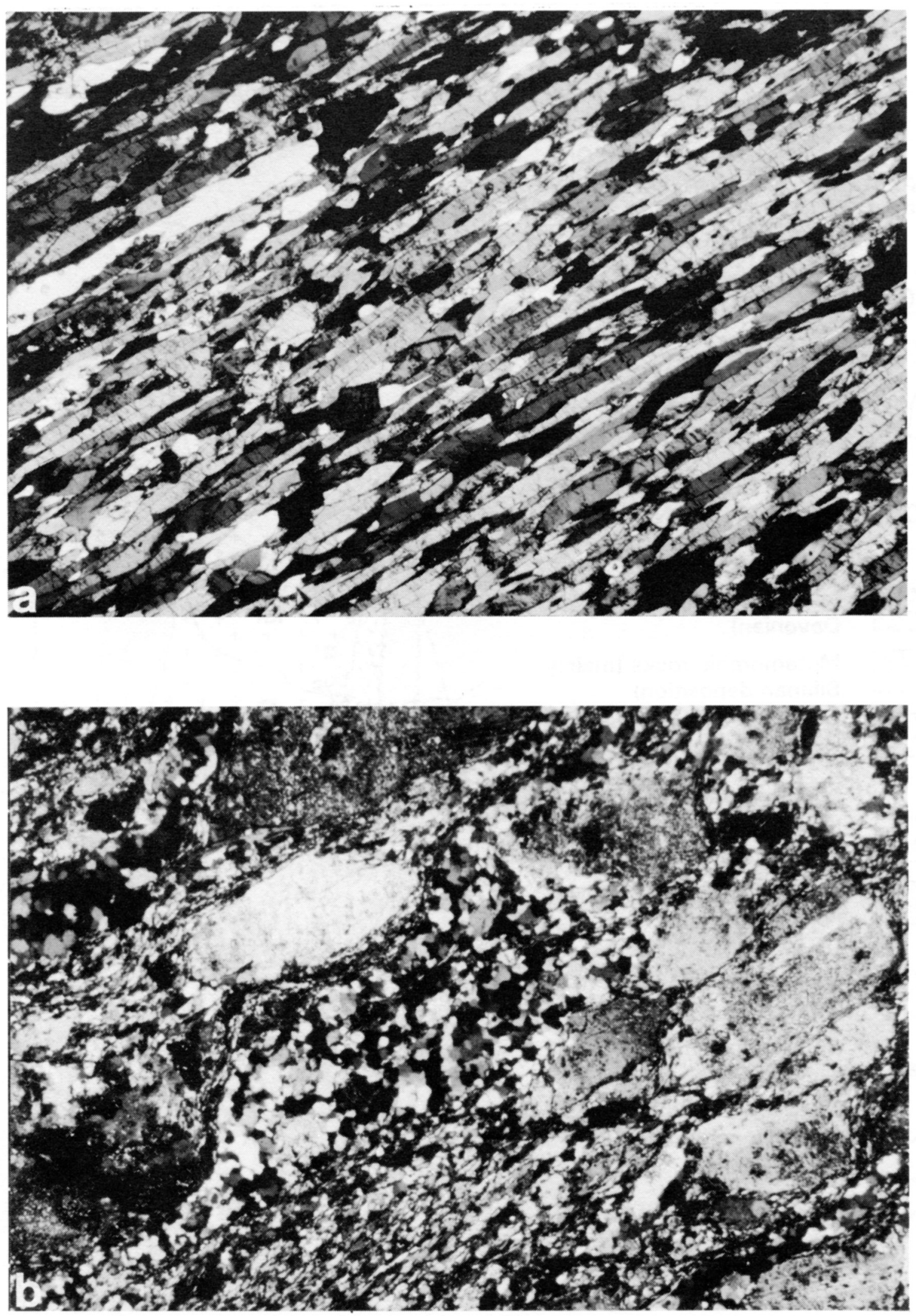

Fig. 2. Photomicrographs of rocks with the gneissic fabric (as described in the text). (a) Thin section of sample SB-84-61 cut parallel to the lineation and perpendicular to the foliation (not pronounced). (b) Thin section of sample SB-84-61 cut perpendicular to both lineation and foliation. 

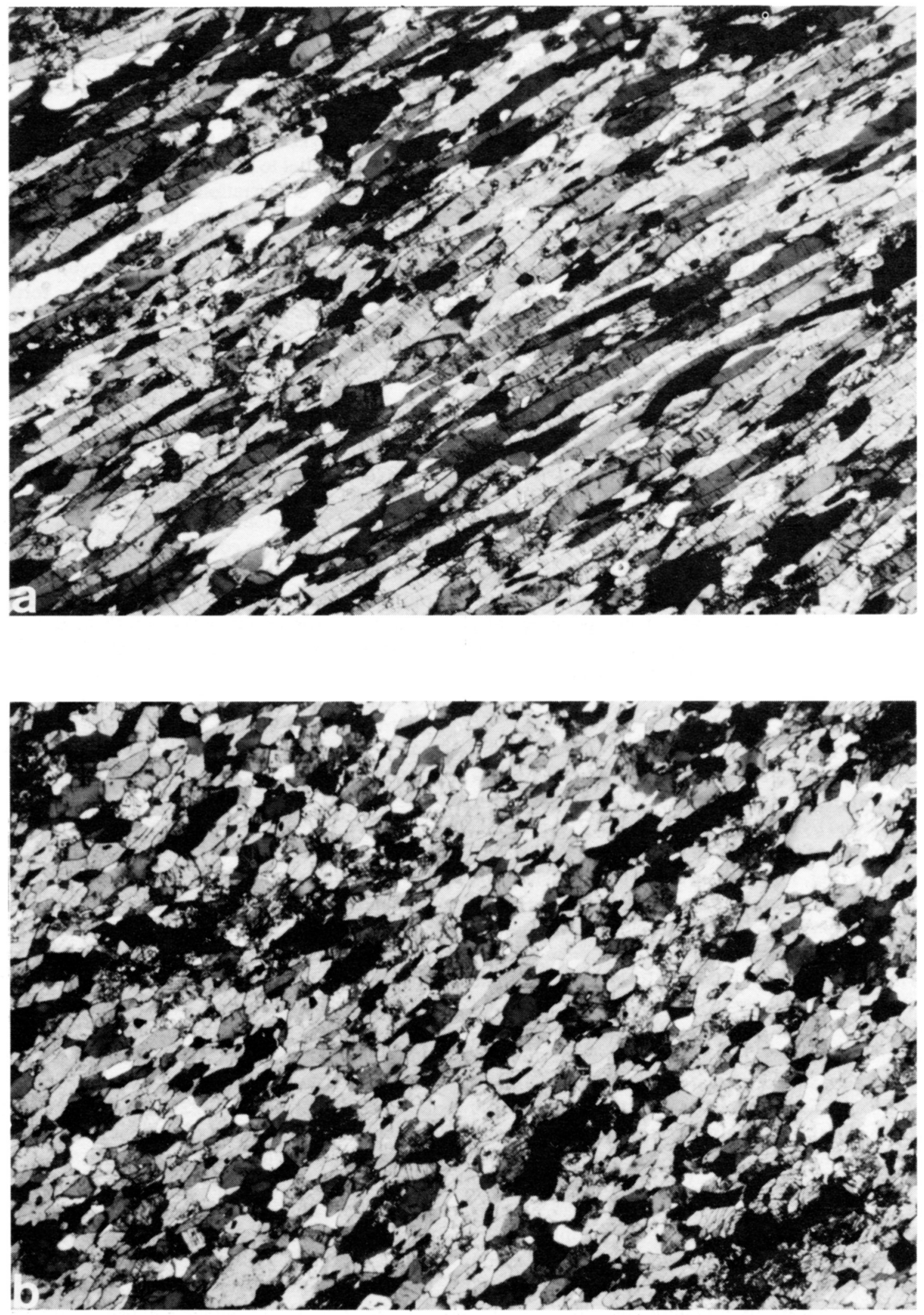

Fig. 3. Photomicrographs of various samples showing classic mylonitic textures. (a) Psammitic or pelitic schist (sample SB-84-153) showing S-and C-surfaces, with mica "fish" and quartz ribbon grains in a groundmass of neoblastic quartz. (b) Mylonitized leucotonalite (sample RR-84-106) showing altered (sericitized) feldspar porphyroclasts in a foliated groundmass of recrystallized quartz and minor chlorite. 
McMillan Flowage Formation and thus part of the Bras d'Or terrane (Fig. 1).

The fault between this enclave of McMillan Flowage Formation and the North Branch Baddeck River Leucotonalite may be part of the EHSZ and may hence represent the boundary between the Aspy and Bras d'Or terranes in this area. This interpretation implies that the North Branch Baddeck River Leucotonalite is also part of the Aspy terrane. However, the assignment of the North Branch Baddeck River Leucotonalite to either the Aspy terrane or Bras d'Or terrane is equivocal. The leucotonalite appears to be entirely faultbounded, with the possible exception of the intrusive contact with the much younger West Branch North River Granite, and is extremely deformed. Most of the thin-sectioned samples collected are mylonitized to varying degrees and consist of sericitized feldspar augen in a fine-grained, foliated matrix of chlorite ( \pm epidote, muscovite) and neoblastic quartz (Fig. 3). The leucotonalite is petrologically distinct from dioritic and tonalitic units of the Bras d'Or terrane (Farrow, 1989), and also appears to be considerably older $(614+38 /-14 \mathrm{Ma}$, Jamieson et al., 1986 compared to ca. 565-555 Ma, Dunning et al., 1990). In the past (e.g., Dunning et al., 1990) the leucotonalite has been considered to be part of the Bras d'Or terrane. However, its inclusion in the Aspy terrane is supported by the presence of an undated but petrologically similar leucotonalite unit in the Aspy terrane in the Mabou Highlands to the southwest (Barr and Macdonald, 1989).

\section{Area B}

The central part (area B, Fig. 1) of the "Bateman Brook Metamorphic Suite" is bounded by the Kathy Road Dioritic Suite on the east and by the West Branch North River Granite and mylonitic rocks of the EHSZ of Raeside and Barr (1990, 1992) on the west (Fig. 1). Based on outcrop pattern, Raeside and Barr $(1990,1992)$ interpreted the contacts with the Kathy Road Dioritic Suite and the West Branch North River Granite to have been originally intrusive.

Rocks in area B of the "Bateman Brook Metamorphic Suite" are different from those in the southern part (area A). They are mainly lineated and foliated diorites and amphibolites, and mafic gneisses. The mineralogy of the diorites/ amphibolites is very similar to that of rocks of the adjacent Kathy Road Dioritic Suite and, like the Kathy Road Dioritic Suite (Farrow, 1989), area B includes a variety of mafic lithologies. In the field, the transition from foliated rocks of the "Bateman Brook Metamorphic Suite" to weakly foliated or non-foliated dioritic rocks of the Kathy Road Suite is moderately abrupt. However, many of the samples of the Kathy Road Dioritic Suite are lineated and the lineation becomes more pronounced towards the west. The "contact" between the "Bateman Brook Metamorphic Suite" and the Kathy Road Dioritic Suite (as defined by Raeside and Barr, 1992) coincides approximately with the appearance of a foliation in the rocks; this is most obvious in rocks with a significant biotite content. Amphibole-rich rocks, though intensely lineated, are generally not strongly foliated even within the "Bateman Brook Metamorphic Suite"(Fig. 2). The protolith of mafic gneisses occurring in the western part of the area may have been either metavolcanic or immature sedimentary rocks. The gneisses and the adjacent Kathy Road Dioritic Suite are intruded by abundant felsic dykes. In places the dykes make up $50 \%$ of the outcrop. They were intruded parallel to the gneissic foliation and appear to have postdated the deformation. The dykes themselves are unfoliated and in places appear to truncate the gneissic fabric. These dykes are interpreted to be protolith to the quartzmuscovite schist noted in area A (above). If so, this implies that the dykes were intruded after the formation of the gneissic fabric but before development of the mylonitic fabric. This supports the argument for two separate episodes of shear, in agreement with the observations of Lin (1992).

We conclude that area B of the "Bateman Brook Metamorphic Suite" consists of sheared dioritic rocks of the Kathy Road Dioritic Suite on the east and gneisses of the McMillan Flowage Formation on the west. Because it lacks classical mylonitic features, the shearing probably occurred under high-grade conditions (Lin, 1992).

On the west, the contact between the "Bateman Brook" unit and the West Branch North River Granite is probably intrusive. The Devonian West Branch North River Granite is therefore intrusive into rocks of both the Bras d'Or and Aspy terranes. Thus it constitutes a "stitching pluton" and its Devonian age (400 $\pm 5 \mathrm{Ma}, \mathrm{Rb}-\mathrm{Sr}$ whole rock, O'BeirneRyan and Jamieson, 1986; 381 and $385 \mathrm{Ma},{ }^{40} \mathrm{Ar} /{ }^{39} \mathrm{Ar}$ biotite plateaux, Reynolds et al., 1989) gives a minimum age for the emplacement of the Bras d'Or terrane against the Aspy terrane.

\section{Area C}

Interpretation of the northern area of the "Bateman Brook Metamorphic Suite" is particularly difficult because exposure in most of this area is very limited. The rocks are a mixture of feldspathic psammite, pelitic and psammitic schist, and banded mafic gneiss. The area is criss-crossed by numerous faults and most of the samples are brecciated or sheared and intensely altered. Instead of an S-shaped bend in the three units (Jumping Brook Metamorphic Suite, mylonite, and "Bateman Brook Metamorphic Suite") proposed for this area by Raeside and Barr (1992), we have re-interpreted these rocks to occur in a series of rhomboid fault-bounded blocks between two dextral strike-slip faults (Fig. 1). The rocks originally assigned to the "Bateman Brook" unit and to the "mylonites" of the Eastern Highlands Shear Zone (see below for further discussion) have been re-assigned to the Jumping Brook Metamorphic Suite of Jamieson et al. (1987). In the northernmost fault-bounded block, just east of the Park Spur Granite (Fig. 1), the samples appear to be metamorphosed immature (feldspar-rich) sedimentary rocks. Rocks of the next block to the south are primarily metapelitic rocks, locally sillimanite-bearing. The southernmost of these blocks, north of the Kathy Road Dioritic Suite (Fig. 1), consists of heterogeneous but mainly mafic gneisses. These commonly 
display pronounced compositional layering and are distinctly different from the lineated and foliated dioritic rocks of the central area to the south (McMillan Flowage Formation). We tentatively correlate them with the George Brook Amphibolite unit of the Jumping Brook Metamorphic Suite of Jamieson et al. (1987).

In addition to assigning rocks previously assigned to the "Bateman Brook Metamorphic Suite" to the Jumping Brook Metamorphic Suite, we have also reassigned part of what was originally ascribed to the Kathy Road diorite to the same unit because virtually no dioritic outcrops occur in this area.

The complex faulting pattern interpreted in the area (Fig. 1) is speculative. It is based, in part, on aeromagnetic data (Nova Scotia Department of Mines and Energy, 1983). These faults are interpreted to occur between the ends of two en echelon dextral strike-slip faults. An idealized diagram of this speculative model for the formation of such a fault system is shown in Figure 4. The operation of dextral motion on the en echelon faults results in normal faulting in the intervening block. Lin (1992) also proposed dextral motion for the later $\left(D_{2}\right)$ deformation in the EHSZ. An idealized regional stress field is shown on Figure 4 and results in normal faults with a northeast trend. However, in detail, individual fault-bounded blocks within such a system may have features that show a clockwise rotation (about a vertical axis), and there may be many subsidiary faults with orientations which have been rotated clockwise from an original northeasterly orientation. The alteration (sericitization, saussuritization, chloritization) that is concentrated in these blocks may have occurred in a zone of "dilation" between the two en echelon dextral strike-slip faults. All the gold show- ings in the study area appear to be in this zone of dilation (Mengel et al., 1991; Smith et al., 1990).

\section{Conclusions}

We conclude that the rocks originally assigned to the "Bateman Brook Metamorphic Suite" are sheared, mylonitized, altered, and fault-bounded blocks of other units from the area. In the south, the former "Bateman Brook" rocks are pelitic schists and minor amphibolite that likely belong to the McMillan Flowage Formation and form an enclave on the western side of the Kathy Road Dioritic Suite, between it and the highly faulted North Branch Baddeck River Leucotonalite, possibly part of the Aspy terrane. The central part of the "Bateman Brook Metamorphic Suite" is interpreted to consist of foliated mafic rocks of the Kathy Road Dioritic Suite on the east and gneisses of the McMillan Flowage Formation on the west. In the north, the rocks of the "Bateman Brook Metamorphic Suite" are intensely sheared and altered and consist of at least three fault-bounded blocks of the Jumping Brook Metamorphic Suite of the Aspy terrane. These faultbounded blocks constitute a zone of dilation that may be the focus of gold mineralization.

In conclusion, all the rocks in the study area are sheared to some degree and thus mark a zone of shear that appears to have operated over a variety of strain conditions (temperature and strain rate particularly) and probably over an extended period of time. This zone of shearing marks the boundary between the Aspy and Bras d'Or terranes as defined by Barr and Raeside (1989) but is not restricted to rocks of one or other terrane.

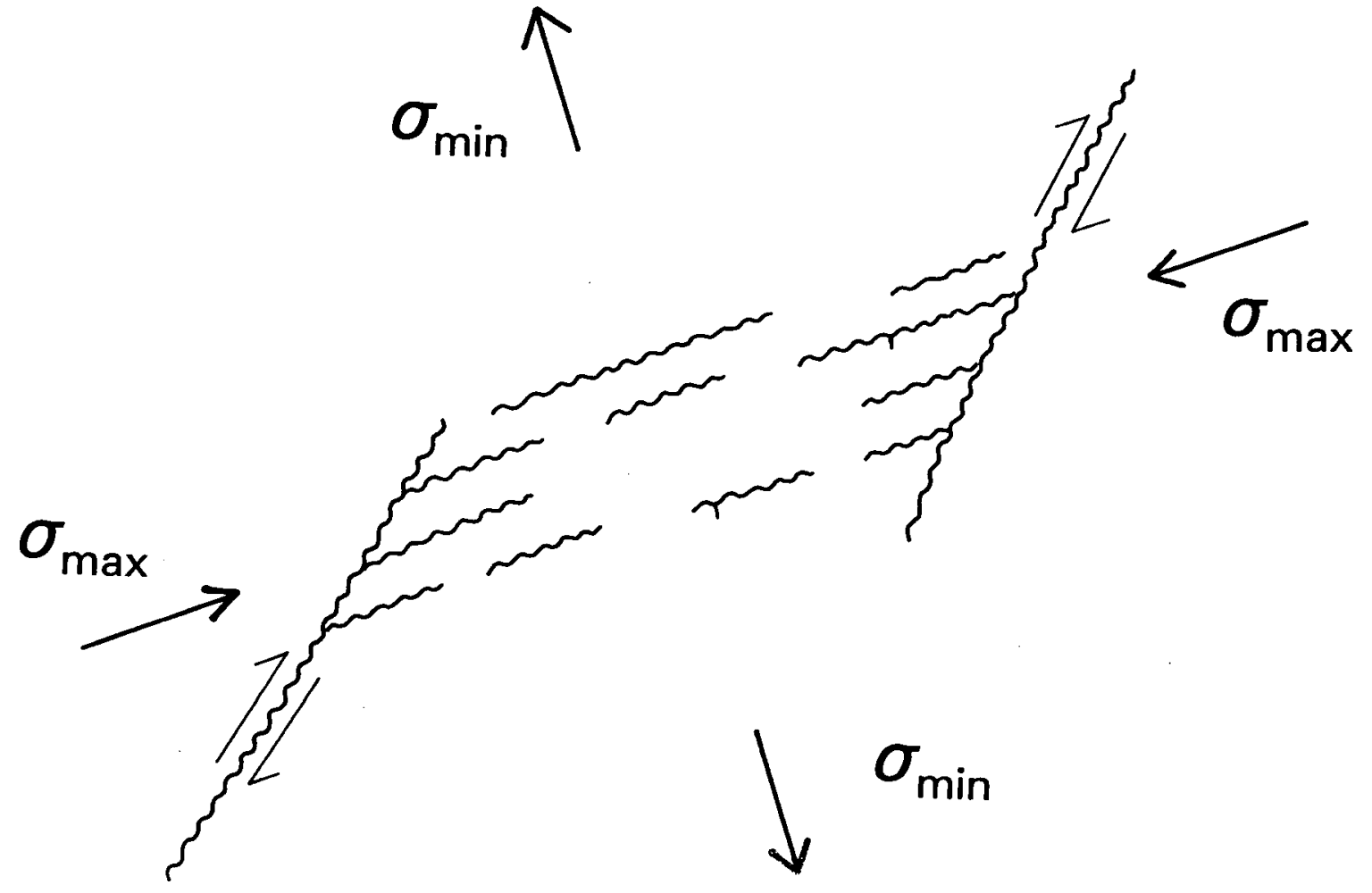

Fig. 4. Idealized configuration of two, en echelon, dextral, strike-slip faults joined by normal faults. Regional maximum ( $\left.\sigma_{\max }\right)$ and minimum $\left(\sigma_{\min }\right)$ stress orientations shown $\left(\sigma_{i n t}\right.$ vertical). Rocks between en echelon faults probably show rotational finite stain. 


\section{ACknowledgements}

This research was funded by a Lithoprobe Supporting Geoscience Contract (to SMB) and is Lithoprobe Publication Number 446. We wish to thank Rebecca Jamieson and Greg Lynch whose constructive criticisms greatly improved an earlier version of this paper.

BarR, S.M. and Macdonald, A.S. 1989. Geology of the Mabou Highlands. Nova Scotia Department of Mines and Energy, Paper 89-2, 65 p.

BARR, S.M. and RAESIDE, R.P. 1989. Tectono-stratigraphic terranes in Cape Breton Island, Nova Scotia: Implications for the configuration of the northern Appalachian orogen. Geology, 17, pp. 822-825.

Dunning, G.R., BarR, S.M., Raeside, R.P., and Jamieson, R.A. 1990. U-Pb zircon, titanite, and monazite ages in the Bras d'Or and Aspy terranes of Cape Breton Island, Nova Scotia: Implications for igneous and metamorphic history. Geological Society of America Bulletin, 102, pp. 322-330.

FARR OW, C.E.G. 1989. Petrography, mineral chemistry, and geochemistry of the dioritic and tonalitic plutons of the southeastern Cape Breton Highlands, Nova Scotia. M.Sc. thesis, Acadia University, Wolfville, Nova Scotia, 320 p.

Hanmer, S. and Passchier, C. 1991. Shear-sense indicators: A review. Geological Survey of Canada, Paper 91-17, 72 p.

Jamieson, R.A., van Breeman, O., Sullivan, R.W., and Currie, K.L. 1986. The age of igneous and metamorphic events in the western Cape Breton Highlands, Nova Scotia. Canadian Journal of Earth Sciences, 23, pp. 1891-1901.

Jamieson, R.A., Tallman, P., Marcotte, J.A., Plint, H.E., and Connors, K.A. 1987. Geology of the west-central Cape Breton Highlands, Nova Scotia. Geological Survey of Canada, Paper 87-13, 11 p.

Jamieson, R.A., BARR, S.M., and Raeside, R.P. 1991. Tectonic implications of ${ }^{40} \mathrm{Ar} /{ }^{39} \mathrm{Ar}$ hornblende ages from late Proterozoic-Cambrian plutons in the Avalon Composite Terrane, Nova Scotia, Canada: Alternative interpretation and reply. Geological Society of America Bulletin, 103, pp. 1376-1383.

KEPPIE, J.D. 1990. Comment on "Tectono-stratigraphic terranes in Cape Breton Island, Nova Scotia: Implications for the configuration of the northern Appalachian orogen". Geology, 18, pp. 669-670.
LIN, S. 1992. The stratigraphy and structural history of the southeastern Cape Breton Highlands National Park and its implications for the tectonic evolution of Cape Breton Island, Nova Scotia, with emphasis on lineations in shear zones. Ph.D. thesis, University of New Brunswick, Fredericton, New Brunswick, $235 \mathrm{p}$.

LynCh, J.V.G. and Tremblay, C. 1992. Imbricate thrusting, reverse-oblique shear, and ductile extensional shear in the Acadian Orogen, central Cape Breton Highlands, Nova Scotia. In Current Research, Part D, Geological Survey of Canada, Paper 92-1D, pp. 91-100.

Mawer, C. 1986. What is a mylonite? Geoscience Canada, 13, pp. 33-34.

Menoel, F., Godue, R., Sangster, A.L., Dubé, B., and Lynch, G. 1991. A progress report on the structural control of gold mineralizations in the Cape Breton Highlands. In Current Research, Part D, Geological Survey of Canada, Paper 911D, pp. 117-127.

Nova Scotia Department of Mines and Energy. 1983. Calculated Vertical Magnetic Gradient Map of the Cape Breton Highlands, Inverness, Victoria and Richmond Counties, Nova Scotia. Map 83-2, Scale 1:125,000.

O'Beirne-Ryan, A.M. and Jamieson, R.A. 1986. Geology of the West Branch North River and the Bothan Brook pluton of the south-central Cape Breton Highlands, Nova Scotia. In Current Research, Part B, Geological Survey of Canada, Paper 86-1B, pp. 191-200.

RAEsIDE, R.P. and BARR, S.M. 1990. Geology and tectonic development of the Bras d'Or suspect terrane, Cape Breton Island, Nova Scotia. Canadian Journal of Earth Science, 27, pp. 1371-1381.

1992. Geology of the northern and eastern Cape Breton Highlands, Nova Scotia. Geological Survey of Canada, Paper 89-14, 39 p.

Reynolds, P.H., Jamieson, R.A., BarR, S.M., and Raeside, R.P. 1989. An ${ }^{40} \mathrm{Ar} /{ }^{39} \mathrm{Ar}$ study of the Cape Breton Highlands, Nova Scotia: thermal histories and tectonic implications. Canadian Journal of Earth Sciences, 26, pp. 2081-2091.

Smith, P.K., Slauenwhite, D.M., and O'Reilly, G.A. 1990. Alteration and gold mineralization in the Cape Breton Highlands, Nova Scotia. In Program and Summaries, Fourteenth Annual Open House and Review of Activities, Nova Scotia Department of Mines and Energy, Report 90-3, p. 30. 